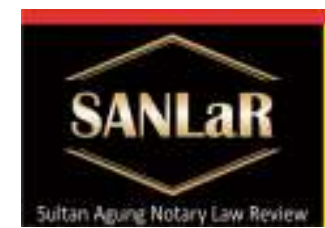

Volume 3 No.4, December 2021
Sultan Aqung

Notary Law Review

Implementation Effectiveness of...(Endah Subekti Tri Astuti \&

\title{
Implementation Effectiveness of Electronic Liability Registration
}

\author{
Endah Subekti Tri Astuti ${ }^{*}$ and Widayati ${ }^{* *}$ ) \\ ${ }^{*}$ Faculty of Law, Universitas Islam Sultan Agung (UNISSULA) Semarang, E- \\ mail: ihndahsubekti90@gmail.com \\ $\left.{ }^{* *}\right)$ Faculty of Law, Universitas Islam Sultan Agung (UNISSULA) Semarang, E-mail: \\ widayati@unissula.ac.id
}

\begin{abstract}
The purpose of this study is to determine and analyze: 1) the effectiveness of the current electronic mortgage registration implementation. 2) Factors that affect the effectiveness of the current implementation of electronic mortgage registration. The approach method used in discussing this research problem is a normative juridical approach. The research specification used is descriptive analytical research. This type of data uses secondary data. The data analysis method used in this research is qualitative data analysis. The results of the study concluded: 1) The implementation of HT registration with the HT-el System at the Land Office has not all been carried out in accordance with the procedures stated in the Technical Guidelines for HT-el. Procedural discrepancies, for example, were found in files that were suspended and closed in 2019 until May 12, 2020. Application files that did not comply with the procedures were discovered based on the results of the Land Office inspection, if not checked, the HT-el certificate would be issued automatically on the seventh day. Issuance without any inspection from the Land Office if there is a procedural error, it is feared that it will become a problem in the future. Obstacles in HT registration with the HT-el System occur in PPAT, Banks as creditors and the Land Office. These obstacles arise during the HT registration process, both technically and non-technically. 2). Barriers related to technical aspects include the lack of facilities such as ranking selection, selecting more than one certificate and providing facilities for checking certificate data in HT-el applications. Meanwhile, in non-technical barriers, there are regulations in Permen ATR/BPN No. 5 of 2020 which is not in accordance with UUHT as the legal basis for the Ministerial Regulation issued, where in UUHT the second sheet of APHT and other warrants are submitted to the Land Office in physical form but in Permen ATR/BPN No. 5 of 2020 only in digital form of scan results.
\end{abstract}

Keywords: Dependents; Effectiveness; Electronic; Right. 


\section{Introduction}

Along with economic development in society, of course, the need for the community will increase rapidly so that people need funds in the form of money. The community does not all have excess funds, because basically there are several community groups that do not yet have a good economy. ${ }^{1}$ On the basis of high needs and the economy has not been able to meet these needs, many people borrow money from banks. Banks are intermediary institutions for parties who have excess funds with parties who lack or require funds that have the function of receiving and distributing funds to the public. ${ }^{2}$

Based on the various explanations above, it is clear that technology has an influence on the order of human life. The era of acceleration of electronic technology, Currently making all aspects of people's lives run with all-digital media, the Minister of ATR/Head of BPN issued Regulation of the Minister of Agrarian Affairs and Spatial Planning of the Head of the National Land Agency Number 9 of 2019 concerning Electronic Integrated Mortgage Services which came into force on June 21, 2019 (Permen ATR/KBPN 9/2019). This provision is issued because it considers the improvement of services, timeliness, speed, convenience and affordability in the context of public services, as well as to adapt legal developments, technology and community needs, it is necessary to utilize information technology so that mortgage service procedures can be integrated electronically so that they become more effective and efficient. The provisions on Mortgage have previously been regulated in UUHT number 4 of 1996 concerning Mortgage on Land and other objects related to Land. The implementation of electronic HT in its development has various problems, including:

1. The legality of electronic signatures has not yet been regulated which blinds the legitimacy of electronic signatures in the manufacture of electronic $\mathrm{HT}$;

2. There is a problem with the timing of changes related to errors in the old electronic HT registration data;

3. Regarding the giving of user names and passwords to other parties, there may be a potential for legal violations that can harm the HT owner who wants to register his Mortgage Rights electronically;

\footnotetext{
${ }^{1}$ Catur Budi Dianawati, Kajian Hukum Jaminan Hak Tanggungan Yang Dilelang Tanpa Proses Permohonan Lelang Eksekusi Ke Ketua Pengadilan Negeri, Jurnal Hukum, Vol. 4 No. 2 June 2017, p. $125-132$.

${ }^{2}$ Hidayat, N., Tanggung Jawab Penanggung Dalam Perjanjian Kredit, Jurnal IImu Hukum Legal Opinion, Vol 2 (4), 2014, p. 1-2
} 
4. Settlement of HT disputes is still traditional, for example, evidence in civil courts which is still not fully based on advances in information and communication technology;

5. Network maintenance that often causes electronic HT registration is also problematic;

6. Not all parties have internet facilities and computer equipment, for example in rural areas in Indonesia.

The various problems above will clearly result in ineffective implementation registration HT Elektronik.in providing legal guarantees for related parties. Credit agreements basically have a certain period of time, within the last time limit of course the debtor as the borrower of money must return the loan money to the creditor along with the interest. In the return process, of course, there are concerns from the creditor that the debtor may not be able to return the borrowed funds in accordance with the existing credit agreement. To reduce worries and gain trust, before the credit agreement occurs, of course, the creditor must apply the precautionary principle. The precautionary principle is important for banks before lending money to debtors, because this principle is to know: ${ }^{3}$

1. The character of the debtor whether he has a good character in doing business and has a responsibility in repaying the loan or not;

2. The ability to pay the debtor financially to repay the loan;

3. Debtor's capital to determine the ability of the debtor to bear the financing burden;

4. Collateral must be worth more than the debtor's loan, which if there is a problem this guarantee can be used to pay off the debtor's debt;

5. Economic conditions to know whether the debtor's business has good future prospects or not.

The need for electronic registration of Mortgage Rights in the presence of various type Weaknesses regarding the management of Mortgage-based registration digital, in its development will give birth to ineffectiveness in society.

\section{Research Methods}

The approach method used in discussing this research problem is a normative juridical approach. The research specification used is descriptive analytical research. Type of data usingdatasecondary. The data analysis method used in this research is qualitative data analysis.

\footnotetext{
${ }^{3}$ Saraswati, R. A. Peranan Analisis Laporan Keuangan, Penilaian Prinsip 5 C Calon Debitur dan Pengawasan Kredit terhadap Efektivitas Pemberian Kredit pada PD BPR Bank Pasar Kabupaten Temanggung, Jurnal Nominal, Barometer Riset Akuntansi dan Manajemen, Vol 1(1), 2012, p. 6.
} 


\section{Results and Discussion}

\subsection{Effectiveness of Current Electronic Mortgage Registration}

Computer network technology is growing rapidly marked by the existence of a LAN (Local Area Network) which is a network in the local area and a larger computer network called a WAN (Wide Area Network). ${ }^{4}$ In general, the rapid development of the internet has also led to various disputes and conflictThe law is quite serious for its users, namely with many unexpected problems that have appeared in the last few years. This is due to the rapid acceleration in the field of information technology. One of them is unexpected progress in the form of ecommerce, including e-governance.

Transactions carried out through the internet media in Indonesia are at the level of conventional not fully reachable by law. ${ }^{5}$ The enactment of Act No. 19 of 2016 concerning Amendments to Act No. 11 of 2008 concerning Electronic Information, becomes the basis for the implementation of an Electronic system in Indonesia.

With regard to the practice of granting credit with guaranteed land rights, a guarantee rights institution is needed that is able to provide legal certainty for interested parties in creating a prosperous, just and prosperous society in accordance with Pancasila and the 1945 Constitution of the Republic of Indonesia. -Act No. 4 of 1996 concerning Mortgage on Land and Objects Related to the Land or abbreviated as "UUHT"6 was then formed to meet the needs of the community regarding this matter.The government provides services including the electronically integrated Mortgage Registration based on the Regulation of the Head of the National Land Agency Number 9 of 2019 and the ATR/BPN Ministerial Regulation Number 5 of 2020 concerning Electronic Mortgage Services and/or hereinafter referred to as "HT-el"

Based on Permen ATR/BPN Number 5 of 2020 concerning Electronically Integrated Mortgage Services, Perkaban Number 9 of 2019 is declared invalid. The preamble to letter a of Permen ATR/BPN Number 5 of 2020 states that this regulation is intended to implement integrated mortgage services in an integrated manner of electronic in order to improve mortgage services that meet the principles of openness, timeliness, speed, convenience and affordability for public services, as well as to adjust legal developments, technology and community needs. Electronic Mortgage Rights relate to the registration of PPAT and/or creditors at the local Land Office. The relationship between PPAT, creditors and debtors in the procedure for making the deed physically does not

\footnotetext{
${ }^{4}$ Anggara, et.al., (2010), Kontroversi UU ITE: Menggugat Pencemaran Nama Baik di Dunia Maya, Jakarta: Penebar Swadaya, p. 3

${ }^{5}$ Iman Sjahputra, (2002), Problematika Hukum Internet Indonesia, Jakarta: Prenhallindo, p. 5.

${ }^{6}$ Ong Argo Victoria, Ade Riusma Ariyana, Devina Arifani. (2020). Code of Ethics and Position of Notary in Indonesia. Sultan Agung Notary Law Review 2 (4), 397-407, http://lppmunissula.com/jurnal.unissula.ac.id/index.php/SANLaR/article/view/13536
} 
change. This can be seen from Article 10 of the Minister of ATR/BPN RI Number 5 of 2020 concerning Electronic Integrated Mortgage Services as follows:

1. PPAT submits the deed and documents for the completeness of the requirements as referred to in Article 9 paragraph (2) through an electronic system of partners that is integrated with the HT-el System.

2. The submission of documents is accompanied by a statement letter regarding the accountability for the validity and correctness of the submitted electronic document data.

3. All documents for completeness of requirements as referred to in paragraph (1) must be kept by PPAT. (4) The format of the Declaration Letter as referred to in paragraph (2) is contained in Appendix I which is an integral part of this Ministerial Regulation.

Users of Electronic Mortgage other than PPAT are creditors who are usually Financial Institutions (Banking) and can also be individuals. For the banking world, of course, it is hoped that the existence of Electronic Mortgage Services can provide benefits, including the punctuality of Mortgage registration on the day of the seventh month after being registered. The registration can be more economical because there is no need to come to the local Land Office. Other benefits include being able to perform Roya and loan transfers quickly, then there is also the convenience of asset management (no need to scan the Mortgage certificate) and can also make reporting and monitoring of the amount and value of Mortgage in all branches of the Bank concerned.

The mechanism for registration of mortgage rights in the electronic system must still be recorded in the land book. This is done by creditors up to print Certificate of Mortgage and attach it to the Certificate of Land Rights. Users of the HT el system service consist of: individuals or legal entities (as creditors), PPAT, and ASN of the Ministry of Agrarian Affairs/BPN. PPAT must use the application provided by the Ministry of ATR/KBPN by becoming a partner at BPN, register and create an account online through the partner portal in a browser at the address: https://mitra.atrbpn.go.id/datappat/login/. If you do not update the data, you will not be able to access and register services on the land service application electronically. So that PPAT cannot become a user in the Electronic Mortgage Rights service. ${ }^{7}$

Service type entitlement dependents in the case of the implementation of HT el that can be submitted through the electronic mortgage system include:

1. Mortgage registration

2. Transfer of mortgage

3. Creditor name change

4. Elimination of mortgage (roya)

\footnotetext{
${ }^{7}$ Source: Ministry of ATR/BPN
} 


\section{Data repair}

The implementation of HT el, which starts from the land office, prepares in advance, among others:

1. Validating all textual data and digital data in the KKP;

2. Ensure the correctness of the PPAT data uploaded to the partner application and ensure that the PPAT is still on active duty according to its working area;

3. Socializing HT el services to PPAT and creditors (banks or other financial institutions);

4. Appointment of ASN and creation of accounts for verifiers and officials signing HT el certificates;

5. Regulating the delegation of authority for the signing of the HT el certificate;

6. Strengthening internal SOPs related to account security in electronic services;

7. Set regional holidays in the application related to the time of birth of $\mathrm{HT}$ el;

8. Improving employee competence in the management of e-mail and e-mail documents;

9. Provide guidance to employees and PPAT not to lend accounts to other parties in HT el services.

The Electronic Mortgage Service, which is based on ATR Regulation Number 5 of 2020, aims to fulfill the principles of openness, timeliness, speed, convenience and affordability. Besides it is also to improve effective and efficient mortgage services by adjusting to legal developments and information technology. The object of Mortgage that can be processed is the object of the Mortgage as regulated in the laws and regulations. The output of this Electronic Mortgage Service is an Electronic Mortgage Certificate for users, namely creditors (can be banking institutions/financial institutions, or individuals) as recipients of Electronic Mortgage Rights.

Online Mortgage Certificate Repair ${ }^{8}$ This can be done if there is a discrepancy between the physical data in the Certificate and the existing digital data. Repair of the Mortgage is given for 30 calendar days from the issuance of the Mortgage and is carried out by the Creditor. Mortgage Documents that can be repaired include rank, Deed Number, Right Holder, Designator, Partial Value, Type and Number of Rights and Other Objects, the form of this repair note is also printed and pasted on the loading record in the Land Rights Certificate which is the object of collateral.

With simultaneous national services that have been in effect since July 8, 2020, we can compare the Electronic Mortgage Service with Conventional Mortgage

8 Ibid. 
Services for its users (PPAT and Creditors) as follows: in Conventional Mortgage Creditors authorize PPAT, deposit HT registration fees, receive certificates from PPAT, receiving an HT certificate after the seventh day, analogue HT certificate products in paper media, and receiving a Land Rights Certificate which has been given a record of loading from PPAT. In the Electronic Mortgage Service, the PPAT uploads the deed to the BPN, submits a copy of the deed and land certificate to the Bank, while the Bank makes an application file electronically (without the need to come to the BPN), pays the registration fee, receives the Electronic HT certificate on the seventh day,

\subsection{Factors Affecting the Effectiveness of the Current Implementation of Electronic Mortgage Registration}

The HT registration process with the HT-el system is preceded by the process of checking land certificates at the Land Office. Then it becomes a standard operating procedure in the implementation of PPAT, before the deed is signed for each object to be transferred or pledged, the certificate of title of the object must be checked with the Land Office. ${ }^{9}$ Registration for checking certificates can be done on condition that they are original from the certificate, a letter of assignment or a checking authorization from the PPAT, an application for checking certificates (application form) that has been provided at the Land Office and a photocopy of the Resident Identity Card (KTP) of the land owner listed on the certificate. Registration for checking certificates is online, but physical files are still being delivered to the office, so not electronically, which is only done by checking at the KKP without sending any more physical files. Obstacles in the implementation of HT-el are faced by both PPAT and Banks as creditors. These obstacles are summarized based on interviews with PPAT informants and bank operators who have experience registering Mortgage Rights with the HT-el System. The obstacles that occur in PPAT include:

1. The problem of PPAT's duties and authorities, which previously submitted and registered $A P H T$, now only submits without registering.

2. There needs to be a choice of ranking in the submission of APHT in the application because it is not once or twice that a ranking error occurs when the Ht-el draft is published.. ${ }^{10}$

3. There needs to be an option to enter more than one certificate for one HT application. (Explanation of Article 2 paragraph (2) UUHT)

\footnotetext{
${ }^{9}$ Putri, CA \& Gunarto. The Effectiveness of Checking Certificates on Prevention of Land Disputes in the Process of Transfer of Land Rights. Deed Journal. Vol. 5 (1), 2018, Unissula, Semarang, p. 269. ${ }^{10}$ Swandi, DNAP, Legal Protection for Mortgage Holder Banks Ranked second in the Execution of Mortgage Objects. Journal of Media luris, Vol. 1(3): 420-438 DOI: 10.20473/mi.v1i3.10183, p. 438.
} 
4. PPAT has doubts regarding the second sheet of APHT whether it is submitted to the creditor or kept by PPAT itself.

Banks as creditors have obstacles, including:

1. It is necessary to add more time for more than three days in payment, because in HT-el there are no working days but calendar days.

2. So that each bank is given more than one operator and supervisor account so that many jobs can be completed on time.

3. So that the limitation per account can only register mortgage rights of 10 files per day, delete or increase the quota. The obstacles raised by the bank operator above have not been known by the HT-el Admin of the Pekanbaru City Land Office.

4. The bank is still difficult to get an account, especially bank branches.

In its implementation, it turns out that obstacles also occur in the Land Office. The obstacles experienced by the Land Office are:

1. The problem of validating land data is still one of the main obstacles in electronic services;

2. The HT-el admin has additional duties because they have to check the certificate at the Computerized Land Office (KKP) for the authenticity of the certificate, its rank and records;

3. Server problems or HT-el applications, if there is a problem, you have to wait until the next day to check the HT-el application. 4) it is necessary to immediately check the land data electronically to speed up the work.

Thus the effectiveness of the implementation of HT registration is caused by the following factors:

1. Juridical Factor

Namely factors that are binding and have a legal basis. ${ }^{11}$ It can be seen from several factors, namely:

a. HT-el . file

The Land Office is still checking/checking files first in accordance with Article 15 paragraph (1) of Act No. 9 of 2019 concerning Electronically Integrated Mortgage Services, to speed up and ensure that the HT-el file is complete or ready for registration. , where this is quite timeconsuming which tends to be long because the inspection is done manually and must be thorough.

b. HT Electronics App

The application system often has errors, so there are obstacles and delays in the registration process and completion of HT-el. In the Electronic Mortgage application, the Land Book and Measurement Letter

\footnotetext{
${ }^{11}$ Misteranswer1, juridical-and-non-juridical factors, accessed on February 29, 2021
} 
must have been validated which can be seen in Article 5 paragraph (2) of Act No. 5 of 2017 concerning Electronic Land Information Services, where the Land Office has not carried out Validation of Land Books and Measurement Letters overall so that the registration process becomes hampered.

2. Non Juridical Factor

Namely factors that come from the association of certain people's lives and are not binding and there are no written rules.

a.

PPAT and banking parties:

Many PPATs are not verified. Meanwhile, the banking sector itself seems to be slow in the registration process and even if it has been verified, it has not been optimal in making logins for the units under it.

b.

Registration:

The HT-el registration process for banks is quite long, where the bank's verification requirements have not been fulfilled.

c.

Process/Time:

The registration process/time or better known as HT-el entry carried out by PPAT is quite long so that until now it is still being assisted by the BPN. d.

Enthusiastic:

PPAT is not yet enthusiastic about HT-el services, it can be seen that $50 \%$ of PPATs still register/register for HT-el services.

\section{Conclusion}

The implementation of HT registration with the HT-el System at the Land Office has not all been carried out in accordance with the procedures stated in the Technical Guidelines for HT-el. Procedural discrepancies, for example, were found in files that were suspended and closed in 2019 until May 12, 2020. Application files that did not comply with the procedures were discovered based on the results of the Land Office inspection, if not checked, the HT-el certificate would be issued automatically on the seventh day. . Issuance without any inspection from the Land Office if there is a procedural error, it is feared that it will become a problem in the future. Obstacles in HT registration with the HT-el System occur in PPAT, Banks as creditors and the Land Office. These obstacles arise during the HT registration process, both technically and non-technically. Barriers related to technical aspects include the lack of facilities such as ranking selection, selecting more than one certificate and providing facilities for checking certificate data in HT-el applications. Meanwhile, in non-technical barriers, there are regulations in Permen ATR/BPN No. 5 of 2020 which is not in accordance with UUHT as the legal basis for the Ministerial Regulation issued, where in UUHT the second sheet of APHT and other warrants are submitted to the Land Office in physical form but in Permen ATR/BPN No. 5 of 2020 only in digital form of scan results. 5 of 2020 which is not in accordance with UUHT as the legal basis 
for the Ministerial Regulation issued, where in UUHT the second sheet of APHT and other warrants are submitted to the Land Office in physical form but in Permen ATR/BPN No. 5 of 2020 only in digital form of scan results. 5 of 2020 which is not in accordance with UUHT as the legal basis for the Ministerial Regulation issued, where in UUHT the second sheet of APHT and other warrants are submitted to the Land Office in physical form but in Permen ATR/BPN No. 5 of 2020 only in digital form of scan results.

\section{References}

Journals:

[1] Catur Budi Dianawati, Kajian Hukum Jaminan Hak Tanggungan Yang Dilelang Tanpa Proses Permohonan Lelang Eksekusi Ke Ketua Pengadilan Negeri, Jurnal Hukum, Vol. 4 No. 2 June 2017

[2] Hidayat, N., Tanggung Jawab Penanggung Dalam Perjanjian Kredit, Jurnal IImu Hukum Legal Opinion, Vol 2 (4), 2014

[3] Ong Argo Victoria, Ade Riusma Ariyana, Devina Arifani. (2020). Code of Ethics and Position of Notary in Indonesia. Sultan Agung Notary Law $\begin{array}{llll}\text { Review } & 2 & \text { (4), 397-407, http://lppm- }\end{array}$ unissula.com/jurnal.unissula.ac.id/index.php/SANLaR/article/view/13536

[4] Putri, C. A. \& Gunarto. Efektivitas Pengecekan Sertifikat Terhadap Pencegahan Sengketa Tanah Dalam Proses Peralihan Hak Atas Tanah. Jurnal Akta. Vol. 5 (1), 2018, Unissula, Semarang.

[5] Saraswati, R. A. Peranan Analisis Laporan Keuangan, Penilaian Prinsip 5C Calon Debitur dan Pengawasan Kredit terhadap Efektivitas Pemberian Kredit pada PD BPR Bank Pasar Kabupaten Temanggung, Jurnal Nominal, Barometer Riset Akuntansi dan Manajemen, Vol 1(1), 2012.

[6] Swandi, D N A P, Perlindungan Hukum Bagi Bank Pemegang Hak Tanggungan Peringkat kedua Dalam Eksekusi Objek Hak Tanggungan. Jurnal Media luris, Vol. 1 (3): 420-438 DOI: 10.20473/mi.v1i3.10183.

Books:

[1]Anggara, et.al., (2010), Kontroversi UU ITE: Menggugat Pencemaran Nama Baik di Dunia Maya, Jakarta: Penebar Swadaya,

[2] Iman Sjahputra, (2002), Problematika Hukum Internet Indonesia, Jakarta: Prenhallindo, 
[3] Marcus Priyo Gunarto, (2011), Kriminalisasai dan Penalisasi dalam Rangka Fungsionalisasi Perda dan Retribusi, Law Doctoral Program of Universitas Diponegoro Semarang.

[4] Peter Mahmud Marzuki, (2017), Penelitian Hukum, Jakarta: Kencana,

[5] Riduan Syahrani, (2009), Rangkuman Intisari Ilmu Hukum, Bandung: Citra Aditya Bakti.

[6]Soerjono Soekanto, (2007), Faktor-Faktor yang Mempengaruhi Penegakan Hukum, Jakarta: Raja Grafindo Persada.

[7] Sri Mahmudji and Soejono Soekanto, (2003), Penelitian Hukum Normatif: Suatu Tinjauan Singkat, Jakarta: Raja Grafindo,

[8] Ulum, Ihyaul MD, (2004), Akuntansi Sektor Publik, Malang: UMM Press.

\section{Regulations:}

[1] Constitution of the Republic of Indonesia 1945.

[2] Act No. 4 of 1996 concerning Mortgage Rights on Land.

[3] Basic Agrarian Act No. 5 of 1960.

[4] Regulation of the Minister of Agrarian Affairs and Spatial Planning of the Head of the National Land Agency Number 9 of 2019 concerning Electronic Integrated Mortgage Services. 